\title{
Synthesis, Characterization, and Catalytic Activity of Sulfided Silico-Alumino-Titanate (Si-Al-Ti) Mixed Oxides Xerogels Supported Ni-Mo Catalyst
}

\author{
Hamad A. Al-Adwani, ${ }^{*}$ N. Thammachote, ${ }^{*}$ T. J. Gardner, ${ }^{+}$and R. G. Anthony* \\ * Kinetics, Catalysis, and Reaction Engineering Laboratory, Department of Chemical Engineering,
A\&M University, College Station, Texas 77843-3122; and ${ }^{+}$Sandia National Laboratories, Albuquerque, \\ New Mexico 87185
}

\begin{abstract}
Layered semicrystalline silico-alumino-titanate ( $\mathrm{Si}-\mathrm{Al}$-Ti) mixed oxides were synthesized by a modified sol-gel method with hydrothermal synthesis temperatures less than $200^{\circ} \mathrm{C}$ and autogenic pressure. The solid products are semicrystalline materials with a surface area of $136-367 \mathrm{~m}^{2} / \mathrm{g}$ and a monomodal pore size distribution with an average pore diameter of $3.6-4.7 \mathrm{~nm}$. The catalytic activity for pyrene hydrogenation in a batch reactor at $300^{\circ} \mathrm{C}$ and 500 psig was determined for sulfided Ni-Mo supported on the Si-Al-Ti mixed oxide. The activity was a function of the support composition, the heat treatment before and after loading the active metals, the addition of organic templates, and different methods of metal loading. The most active sulfided Ni-Mo/Si-Al-Ti catalyst has an activity in the same range as the commercial catalyst, Shell 324 , but the metal loading is $37 \%$ less than the commercial catalyst.
\end{abstract}

\section{INTRODUCTION}

Many different methods have been reported for synthesizing mixed oxide supports like $\mathrm{Si}-\mathrm{Ti}$ (1-11), Si-Al (12-16), Al-Ti (17-19), Ti-Zr (20, 21), Si-Ce (22), Zr-Si (23), Ti-Zr-V (24), and La-Al (25). These methods include sol-gel precipitation, coprecipitation, intercalation, and impregnation. Different methods of preparation give different results in the physical structure, surface properties, and catalytic activity. Mixed oxides have been used as catalysts supports for many catalytic reactions, such as hydrotreating $(1-3,6,13$, $16-21,24-26)$, oxidation (7), reforming $(11,23,24)$, and epoxidation (26), due to their high surface areas, surface acidities, and strong metal-support interactions.

Coal liquefaction processes have been successfully operated by using hydrocarbon solvents or recycled coal derived liquids, e.g., the Exxon donor-solvent process, the solvent refined Coal II process, the integrated two-stage liquefaction process, and the Chevron coal liquefaction process (27). The solvents act as hydrogen transfer agents in processing the coal liquids to higher valued products. Polycyclic aromatic hydrocarbons such as anthracene, fluoranthene, phenanthrene, and pyrene are significantly represented in the coal liquid. Pyrene reacts with hydrogen to form hydropyrene, which further reacts with coal to produce coal derived liquids. Studies at Sandia National Laboratories showed that the catalytic activity of pyrene hydrogenation correlated with ultimate activity for direct coal liquefaction $(28,29)$. Therefore, pyrene was chosen as a model compound to determine the hydrogenation activity of sulfided Ni-Mo/Si-Al-Ti catalysts.

Hydrous titanium oxides (28) have been used as supports for $\mathrm{Ni}, \mathrm{Mo}$, and $\mathrm{Pd}$ catalysts for hydrotreating reactions (28-30), hydroprocessing of heavy oil and coal liquids $(31,32)$, and direct coal liquefaction (33, 34). Initial interest in hydrous metal oxides prepared by a reaction between an alcohol-soluble base and a metal alkoxide was synthesis of electroactive ceramic materials. The metals in the alkoxides used in the preparation were $\mathrm{Ti}, \mathrm{Zr}$, and $\mathrm{Nb}$. High ion exchange capacities (up to $5 \mathrm{meq} / \mathrm{g}$ ) and high surface areas are some of the interesting characteristics of these amphoteric materials. Hydrous niobium oxide (HNO), 


\section{DISCLAIMER}

This report was prepared as an account of work sponsored by an agency of the United States Government. Neither the United States Government nor any agency thereof, nor any of their employees, make any warranty, express or implied, or assumes any legal liability or responsibility for the accuracy, completeness, or usefulness of any information, apparatus, product, or process disclosed, or represents that its use would not infringe privately owned rights. Reference herein to any specific commercial product, process, or service by trade name, trademark, manufacturer, or otherwise does not necessarily constitute or imply its endorsement, recommendation, or favoring by the United States Government or any agency thereof. The views and opinions of authors expressed herein do not necessarily state or reflect those of the United States Government or any agency thereof. 


\section{DISCLAIMER}

Portions of this document may be illegible in electronic image products. Images are produced from the best available original document. 
hydrous zirconium oxide (HZO), and hydrous titanium oxide (HTO) were all evaluated as catalyst supports for coal liquefaction (34). Active HTO catalysts were synthesized by ion exchanging the sodium ion in the amorphous Na-HTO for active metal ions like Ni, Mo, or Pd. Batch microreactor experiments $(28,29)$ indicated high activity toward coal liquefaction for sulfided Ni-Mo supported on the HTO.

At elevated temperatures, HTO supports experience a phase transformation from amorphous to microcrystalline anatase titania. By using the same chemical system for preparing HTO materials, Anthony and Dosch (35) invented five new crystalline titanates (CT) that would not undergo this transformation. These new crystalline titanates were classified according to their method of synthesis, surface area and pore size distributions, and XRD patterns. The new CT materials had a layered structure with high surface area and ion exchange capacity.

Four of the new CT materials were loaded with $\mathrm{Pd}$ by ion exchange. They all showed higher hydrogenation activity than those of $\mathrm{Pd} /$ anatase and $\mathrm{Pd} / \mathrm{HTO}$ catalysts. The one labeled $\mathrm{Pd} / \mathrm{T} 2 \mathrm{CT}$ had the highest activity for the hydrogenation of hexene and pyrene (35). The hydrothermal synthesis of T2CT (Type 2 crystalline titanate as defined by Anthony and Dosch (35)) was successfully scaled from 3 to $100 \mathrm{~g}$ per batch (36). Upon scale-up, the surface area decreased from 207 to $160-170 \mathrm{~m}^{2} / \mathrm{g}$, while other characteristics remained unchanged. They also reported the composition of T2CT to be $\mathrm{Na}_{0.47} \mathrm{Al}_{0.015} \mathrm{Ti}$. Sulfided NiMo/T2CT had a catalytic activity comparable to that of commercial catalysts with similar metal loading. However, after calcining $\mathrm{T} 2 \mathrm{CT}$ at $500^{\circ} \mathrm{C}$ the surface area significantly decreased, and crystalline $\mathrm{Na}_{0.33} \mathrm{TiO}_{2}$ was identified.

Despite the promising catalytic activity of $\mathrm{T} 2 \mathrm{CT}$ supported catalysts, the material is thermally unstable at temperatures above $500^{\circ} \mathrm{C}$. Introducing thermally stable compounds between the layers of T2CT should significantly improve the stability. The intercalation of T2CT with n-alkylamines and tetraethylorthosilicate (TEOS) was used to improve the stability of T2CT (3). Thermally stable T2CT was produced by first swelling the acidified T2CT with an alkylamine (n-butylamine, n-octylamine, and n-dodecylamine) and subsequently intercalating with TEOS. The interlayer distance was directly proportional to the alkylamine chain length. The catalytic activity was inversely proportional to the silica content, whereas the alkylamine chain length had no effect on the catalytic activity of the sulfided NiMo/Si-T2CT. High surface areas were attained after calcination at $450^{\circ} \mathrm{C}$ for $4 \mathrm{~h}$. In addition, the catalyst had higher activity than that of the commercial catalysts (Shell 324 and AMOCAT 1C) for pyrene hydrogenation. However, the layers of $\mathrm{T} 2 \mathrm{CT}$ became. extremely disordered after calcination under the above-mentioned conditions.

The work presented in this paper shows that novel Si-Al-Ti materials can be synthesized using a modified sol-gel method with a hydrothermal synthesis temperature of $150-170^{\circ} \mathrm{C}$ and autogenous pressure. The materials have high surface areas and ion-exchange capacities of 3.24 to $4.2 \mathrm{meq} / \mathrm{g}$ after calcination at $500^{\circ} \mathrm{C}$. The ion-exchange capacity was a function of the $\mathrm{Si} / \mathrm{Ti}$ mole ratio and the calcination temperature. As the $\mathrm{Si} / \mathrm{Ti}$ or the calcination temperature increases, the ion-exchange capacity decreases. The as-prepared materials were semicrystalline; however, after removing the sodium cation by treating the material with an acid and then calcining, the material structure changes to mixed phases of anatase titania and amorphous solid. In this paper, the synthesis and characterization of Si-Al-Ti materials and the catalytic activity of the $\mathrm{Ni}-\mathrm{Mo} / \mathrm{Si}-\mathrm{Al}-\mathrm{Ti}$ for pyrene hydrogenation are presented. The effects of the thermal treatment of the support and the catalyst pretreatment on the catalytic activity were evaluated. Different methods of Mo loading such as incipient wetness with and without $\mathrm{pH}$ control and ion-exchange were investigated. The use of an organic template in the synthesis of the support and different synthesis compositions were investigated. 


\section{Support Synthesis}

Si-Al-Ti mixed oxides were synthesized by first mixing tetraethylorthosilicate with titanium (IV) isopropoxide (tetraisopropoxide titanate). The solution was then added to an aqueous solution of sodium hydroxide, aluminum nitrate nanohydrate, and a solution of $25 \%$ tetramethyl ammonium hydroxide (TMAOH) in methanol, causing heat to evolve. Stirring and slow addition of TEOS and TIPT solution were required to prevent boil-over of the solution. White precipitate formed instantly. After this step, the slurry was loaded into a reactor and heated at a temperature of $150-170^{\circ} \mathrm{C}$ for $12 \mathrm{~h}$ at autogenic pressure. The mole ratio of the feed for a standard $\mathrm{Si}-\mathrm{Al}-\mathrm{Ti}$ sample preparation was NaOH:TMAOH:Al:water:TEOS:TIPT $=0.5: 0.5: 0.05: 50: 0.25: 1$. Nevertheless, synthesis compositions, such as $\mathrm{Al} / \mathrm{Ti}, \mathrm{Si} / \mathrm{Ti}$, and $\mathrm{TMAOH} / \mathrm{Ti}$ mole ratios, varied; i.e., not all of the charge went into the solid product. After the hydrothermal synthesis, the reactor was cooled rapidly by tap water. The solid product was washed and filtered three times with water and another three times with acetone to remove the excess sodium and organic compounds.

\section{Support Treatment and Characterization}

In the synthesis procedure, sodium hydroxide is one of the main compounds; however, sodium is very poisonous to pyrene hydrogenation. Therefore, the material cannot be used as a catalyst support before treating it with an acid to ion-exchange the sodium with hydrogen. The Si-Al-Ti can be ion-exchanged either before or after calcination. Therefore, the materials were divided into three groups: the first group was acidified only, the second group was acidified and then calcined at $500^{\circ} \mathrm{C}$ for $4 \mathrm{~h}$ with a heating rate of $20^{\circ} \mathrm{C} / \mathrm{min}$, and the third group was calcined first and then acidified.

Several methods were used to characterize these novel materials. BET data were obtained by using a Micomeretics Digisorb 2600 and ASAP 2010. Powder X-ray diffraction data were collected by using a Scintag XDS $2000 \mathrm{X}$-ray diffractometer. A Varian AA-30 spectrometer was used to determine elemental composition.

\section{Metal Loading}

Different methods of Mo loading such as incipient wetness with or without controlled $\mathrm{pH}$ and ionexchange were used. Without adding acid, the $\mathrm{pH}$ of a mixture of acidified $\mathrm{Si}-\mathrm{Al}-\mathrm{Ti}$ and an aqueous solution of ammonium molybdate (VI) tetrahydrate was between 5 and 6 . An acid was added to control the $\mathrm{pH}$ to around 3. The idea of adding the acid was to increase the amount of molybdenum anion adsorbed on the support whose surface charge is positive due to the acidic environment. Different acids such as nitric acid and sulfuric acid were used. After Mo loading, the catalyst was dried in an oven at $100^{\circ} \mathrm{C}$ before it was impregnated with an aqueous solution of nickel nitrate nanohydrate at a weight ratio of $\mathrm{Ni}$ to Mo of 0.3 .

\section{Catalyst Pretreatment and Activity Test for Hydrogenation of Pyrene}

The as-prepared Ni-Mo/Si-Al-Ti catalysts were in a powdered form. The catalyst was pressed under high pressure to form a pellet without adding any binder. The pellet was then ground to $-10 /+20$ mesh size. The catalysts were divided into two groups. One group was first calcined at $500^{\circ} \mathrm{C}$ for $1 \mathrm{~h}$ in air and then sulfided with $10 \% \mathrm{H}_{2} \mathrm{~S}$ in $\mathrm{H}_{2}$ at $420^{\circ} \mathrm{C}$ for $2 \mathrm{~h}$ in a flow reactor. The second group was sulfided under the same conditions as the first group without precalcination. After sulfiding, the catalyst was ground to -200 mesh size. Typically $100 \mathrm{mg}$ pyrene, $1000 \mathrm{mg}$ hexadecane, and $10 \mathrm{mg}$ catalyst were loaded into stainless steel microreactors equipped with a thermocouple and a pressure transducer. The reactors were pressurized 
by hydrogen and then heated in a fluidized sand bath. The heat-up period took about $1 \mathrm{~min}$. The reaction conditions were $300^{\circ} \mathrm{C}$ and $600 \mathrm{psig}$ of hydrogen (cold charge) with a reaction time of $10 \mathrm{~min}$. The experimental setup and product analysis are given in detail by Dosch and McLaughlin (36). The hydrogenation reaction rate was modeled by pseudo-first-order kinetics due to the excess hydrogen concentration and the fact that dihydropyrene is a main reaction product at the experimental conditions (36). All the catalyst pretreatment, activity studies for pyrene hydrogenation, and the determination of actual $\mathrm{Ni}$ and Mo compositions were performed at Sandia National Laboratories.

\section{RESULTS AND DISCUSSION}

\section{Support Synthesis}

Table 1 shows the synthesis condition and the final product composition of the Si-Al-Ti materials. In all synthesis procedures the molar ratio of $\mathrm{NaOH}: \mathrm{TMAOH}: \mathrm{H}_{2} \mathrm{O}$ :TIPT mole ratio was 0.5:0.5:50:1, except for NT60 in which TMAOH was replaced with NaOH. The synthesis mole ratio of NT60 is 1.0:0.0:50:1. NT58 is a replicate of NT51, and the reproducibility of the synthesis is illustrated. The synthesis conditions of NT52 and 53 are the same as those of NT57 and 59, respectively, except for the reactor size, which was increased from 75 to $600 \mathrm{ml}$. The data in Table 1 indicate that the addition of Si to the feed increases the amount of $\mathrm{Al}$ in the product. Figure 1 shows the X-ray diffraction (XRD) pattern of the as-prepared Si-AlTi samples NT54-56. With a constant Si/Ti synthesis mole ratio of 0.25 , the $\mathrm{Al} / \mathrm{Ti}$ mole ratio was varied from 0.0 to 0.2 . The XRD pattern changed from semicrystalline to an amorphous structure as the Al/Ti mole ratio increased. Similar results are shown in Fig. 2 for the XRD pattern of Si-Al-Ti samples NT57-59. With a constant $\mathrm{Al} / \mathrm{Ti}$ mole ratio of 0.05 the $\mathrm{Si} / \mathrm{Ti}$ mole ratio was varied from 0.15 to 0.5 . As the $\mathrm{Si} / \mathrm{Ti}$ mole ratio increases, the $d_{0}$ spacing increases and the material becomes less crystalline. There is no remarkable difference in the XRD patterns of the samples prepared with different size reactors and those of the sample prepared with or without TMAOH.

Table 1 indicates that as the $\mathrm{Si} / \mathrm{Ti}$ mole ratio in the synthesis increases (NT51-53 or 57-59), $\mathrm{Si} / \mathrm{Ti}$ and $\mathrm{Al} / \mathrm{Ti}$ mole ratios recovered in the final solid product increase. Similarly, as the Al/Ti mole ratio in the synthesis increases (NT54-56), $\mathrm{Al} / \mathrm{Ti}$ and $\mathrm{Si} / \mathrm{Ti}$ mole ratios in the solid product increase. These results suggest that both silicon and aluminum addition to the synthesis form either mixtures of silico-aluminate and titanate compounds or new amorphous Si-Ti-Al metal oxides.

\section{Support Treatment}

The as-prepared (sodium form) samples have thermally stable structures. After calcination at $500^{\circ} \mathrm{C}$ for 4 $\mathrm{h}$ with a heating rate of $2^{\circ} \mathrm{C} / \mathrm{min}$, the materials still show a semicrystalline structure. Figure 3 shows the $\mathrm{XRD}$ pattern of the sodium form Si-Al-Ti materials with $\mathrm{Si} / \mathrm{Ti}=0.25$ and $\mathrm{AV} / \mathrm{Ti}=0.05$ after calcination at different temperatures. The XRD pattern did not change after calcination. The same results were found with all the sodium form samples with $\mathrm{Al} / \mathrm{Ti}$ mole ratio of 0.05 and $\mathrm{Si} / \mathrm{Ti}$ mole ratio of $0-0.5$.

The structure of the acid-treated, i.e., hydrogen form, samples changed from semicrystalline to a mixed phase of amorphous and anatase titania materials after calcination at $500^{\circ} \mathrm{C}$ for $4 \mathrm{~h}$. Figure 4 shows the XRD patterns of the acidified NT54-56 after calcination at $500^{\circ} \mathrm{C}$. As the Al/Ti mole ratio in the synthesis increased, the Si-Al-Ti material structure became more amorphous. A similar result can be observed in Fig. 5 for the XRD pattern of the acidified Si-Al-Ti materials after calcination at $500^{\circ} \mathrm{C}$ for $4 \mathrm{~h}$. 
Table 2 indicates that the surface areas, pore volumes, and average pore diameters of the supports are a function of support composition, support pretreatment, and synthesis conditions. As the Al/Ti or the $\mathrm{Si} / \mathrm{Ti}$ mole ratios are increased in supports \#1-3 and \#4-6, respectively, the surface areas and total pore volumes increase, but the average pore diameters do not change. Figures 6 and 7 show the differential pore volume distribution for $\mathrm{Si}$-Al-Ti supports with different silica and alumina contents. All of the samples have a very narrow monomodal pore size distribution with an average pore diameter of about $4 \mathrm{~nm}$. Figure 8 illustrates the differential pore volume distribution plot for $\mathrm{Si}-\mathrm{Al}$-Ti samples prepared with and without the organic template, TMAOH. The pore volume distribution of Si-Al-Ti samples prepared without TMAOH was broader and the average pore diameter increased about $1 \mathrm{~nm}$.

Moreover, the surface area and the total pore volume of the samples prepared without TMAOH (supports \#16 and 17) are greater than those of samples prepared with TMAOH (supports \#4 and \#14), even though the same $\mathrm{Si} / \mathrm{Ti}$ and $\mathrm{Al} / \mathrm{Ti}$ mole ratios were used in the synthesis. The surface areas of the acidified supports are greater than those of either the acidified and then"calcined supports or the calcined and then acidified supports. All samples have a monomodal pore size distribution except for support \#17, calcined and then acidified NT60, which has a bimodal pore size distribution. The difference in surface area, pore volume, and average pore diameter of samples prepared under the same conditions with the same composition but different reactor size (NT52, 53 and NT57, 59) was negligible.

\section{Pyrene Hydrogenation Activity Test}

Table 3 shows the different methods of Mo loading and the atomic absorption (AA) analysis of the actual catalyst composition of $\mathrm{Ni}$ and $\mathrm{Mo}$, the physical properties, and catalytic activities for pyrene hydrogenation for Ni-Mo/Si-Al-Ti catalysts and a commercial catalyst (Shell 324). The weight percentage of Ni and Mo in the catalyst was based on the catalyst weight after calcination at $500^{\circ} \mathrm{C}$. To reduce the work load of checking the actual $\mathrm{Ni}$ and $\mathrm{Mo}$ content in each catalyst, only some are tested for $\mathrm{Ni}$ composition. Ni was loaded onto the catalyst by incipient wetness at $30 \mathrm{wt} \%$ of the Mo loaded on the catalyst.

For catalysts \#1-3 synthesized with constant Si/Ti mole ratio of 0.25 and $\mathrm{Al} / \mathrm{Ti}$ mole ratios from 0 to 0.2 , catalyst \#2 (NT55) with Si/Ti of 0.25 and Al/Ti of 0.1 , has the maximum pyrene hydrogenation activity for both calcined and then sulfided and sulfided only catalysts. However, for this set the activity per mass of catalyst is less than the Shell 324 probably because of the lower Mo content.

For catalysts \#4-6 (NT51) synthesized with constant $\mathrm{Al} / \mathrm{Ti}$ mole ratio of 0.05 and $\mathrm{Si} / \mathrm{Ti}$ mole ratio from 0.15 to 0.5 , catalyst \#6 with $\mathrm{Al} / \mathrm{Ti}=0.05$ and $\mathrm{Si} / \mathrm{Ti}$ of 0.25 has the maximum pyrene hydrogenation activity for both calcined and then sulfided and sulfided only catalysts. By utilizing the activities for the calcined and then sulfided catalyst, the following activity criteria can be inferred: Mo loading without using acid $\geq$ Mo loading with sulfuric acid $>$ Mo loading with nitric acid. The use of the acid did not improve the catalyst activity.

For the sulfided only catalyst, the order of the catalyst activity was the opposite. The catalytic activities were very poor for both calcined and then sulfided and sulfided only catalysts. The result suggests that there is a maximum activity for the Mo content as a high Mo loading yields an inactive catalyst. This is probably due to the poor distribution of Mo on the surface of the support at high Mo loading. Calcined and then sulfided catalyst \#12, acidified NT51 with $7.96 \%$ Mo loading by ion-exchange, has higher catalytic activity than those of catalysts \#4, 7, 10, 11, which were also prepared from NT51 with different treatments. However, sulfided only catalyst \#12 has the lowest activity. As a result, for calcined and then sulfided 
catalyst, the Mo loading by ion-exchange gives the best activity; however, for sulfided only catalysts, the Mo loading by impregnation with nitric acid gives the most active catalysts.

Different support pretreatments gave different results in pyrene hydrogenation catalyst activity as indicated by the $k$ values in Table 3. For Ni-Mo/Si-Al-Ti catalysts synthesized at Si/Ti mole ratios of 0.15 and 0.25 , the acidified only catalysts (catalysts \#18 and 19) have the highest activity compared to the acidified and then calcined catalysts (catalysts \#4 and 5) or the calcined and then acidified catalysts (catalysts \#13 and 14). These results imply that the higher surface area and higher ion-exchange capacity of the acidified support is more important for preparing active catalysts than the support's thermal stability. However, for catalysts synthesized with Si/Ti mole ratio of 0.5 (catalysts \#6, 15, 20), there is no remarkable difference in the activity when different pretreatment methods are used.

The most active Ni-Mo/Si-Al-Ti catalyst, catalyst \#16, was synthesized with Si/Ti and Al/Ti mole ratios of 0.25 and 0.05 , respectively, but without using the organic template TMAOH. Compared with catalyst \#4, which was synthesized under the same condition but with the addition of TMAOH, catalyst \#16 activity was $80 \%$ higher for both of the calcined and then sulfided catalyst and the sulfided only catalyst. The higher activity may be due to the larger surface area, total pore volume, and average pore diameter of the support synthesized without using TMAOH (Table 2). The activity of catalyst \#16 is similar to that of the commercial catalyst Shell 324 , on a catalyst weight basis. However, compared to Shell 324, catalyst \#16 had a smaller amount of Mo loading; therefore, the rate constant per gram Mo loading of the $\mathrm{Ni}-\mathrm{Mo} / \mathrm{Si}-\mathrm{Al}$ Ti catalyst was much higher than that of the Shell catalyst.

The most active catalyst on the basis of Mo were numbers 2 (NT55), 6 (NT59), 10 (NT51), 11 (NT51), 12 (NT51), 16 (NT60), and 17 (NT60). The common characteristics of these materials were they were all calcined and sulfided or it made no difference, and \#2-11 were acidified and calcined prior to Mo-Ni loading and \#12 was acidified only. Catalyst NT60 appeared to be more active for the acidified and calcined, i.e., $\# 16$, than \#17, which was calcined and then acidified.

The characteristics and methods of treatment of the most active catalysts are summarized in Table 4.

\section{CONCLUSIONS}

1. Novel, high surface area, and high ion-exchange capacity Si-Al-Ti materials were synthesized by a modified sol-gel method with hydrothermal synthesis at $150-170^{\circ} \mathrm{C}$ and autogenous pressure.

2. Thermal pretreatment of the Si-Al-Ti support prior to acidification did not improve the catalyst activity. With the exception of the NT60 support prepared without TMAOH, calcining prior to acidification resulted in significantly decreasing the catalyst activity.

3. For calcined and then sulfided catalyst, Mo loading by ion-exchange gives the most active catalyst, while, for sulfided only catalyst, Mo loading by impregnation with the use of nitric acid to control the $\mathrm{pH}$ gives the most active catalyst.

4. There is an optimum Mo composition on the Si-Al-Ti support. Loadings higher than the optimum produce inactive catalysts, which is probably due to the lack of dispersion.

5. The catalytic activity is a function of the support composition. Active catalysts can be synthesized with $\mathrm{Al} / \mathrm{Ti}$ and $\mathrm{Si} / \mathrm{Ti}$ mole ratios of $0.05-0.1$ and $0.25-0.5$, respectively. 
6. At present, the most active $\mathrm{Ni}-\mathrm{Mo} / \mathrm{Si}-\mathrm{Al} / \mathrm{Ti}$ catalyst was synthesized with $\mathrm{Si} / \mathrm{Ti}$ mole ratio of 0.25 and $\mathrm{A} 1 / \mathrm{Ti}$ mole ratio of 0.05 , without using the organic template, TMAOH. The catalyst activity on a per mass basis was equal to the activity of Shell 324 , but based on the amount of metals on the support the activity was significantly greater than the activity of Shell 324 catalyst.

7. The most active catalyst, \#16 (NT60), was prepared by synthesis at $170^{\circ} \mathrm{C}$, acidified and calcined, and impregnated with Mo by controlling the $\mathrm{pH}$ at 3 to 4 with nitric acid, i.e., ion pair adsorption or ion exchange with the proton, impregnation with $\mathrm{Ni}\left(\mathrm{NO}_{3}\right)_{2}$ and calcining and sulfiding. Of particular note are the most active catalysts had Al/Ti ratios of 0.03 or greater, and Si/Ti ratios of 0.15 to 0.37 .

\section{ACKNOWLEDGMENTS}

The financial support of this research by Sandia National Laboratories for Texas A\&M Research Foundation projects 8346 and 8940 and by the U.S. Department of Energy at Sandia National Laboratories under Contract DE-ACO4-76DP000789 is appreciated. The kinetic experiments on pyrene hydrogenation were performed at Sandia National Laboratories.

\section{REFERENCES}

Sandia is a multiprogram laboratory operated by Sandia Corporation, a Lockheed Martin Company, for the United States Department of Energy under contract DE-AC04-94AL85000.

1. Udomsak, S., Anthony, R. G., and Lott, S. E., Appl. Catal. A 122, 111 (1995).

2. Udomsak, S., Nge, R., Anthony, R. G., Dufner, D. C., and Lott, S. E., in "Prep. Pap - Sixth International Symposium on Scientific Bases for the Preparation of Heterogeneous Catalysts," Vol. 1, p. 399, 1994.

3. Udomsak, S., and Anthony, R. G., Catal. Today 21, 197 (1994).

4. Dutoit, D.C.M., Schneider, M., and Baiker, A., J. Catal. 153,165 (1995).

5. Doolin, P. K., Alerasool, S., Zalewski, D. J., and Hoffman, J. F, Catal. Lett. 25, 209 (1994).

6. Kumbhar, P. S., AppI. Catal. A 96, 241 (1993).

7. Imamura, S., Ishida, S., Tarumoto, H., Saito, Y., and Ito, T., J. Chem. Soc. Faraday Trans. 89(4), 757 (1993).

8. Sohn, J. R., and Jang, H. J., J. Catal. 136, 267 (1992).

9. Odenbrand, C. U. I., Andersson, S. L. T., Andersson, L. A. H., Brandin, J. G. M., and Busca, G., $J$. Catal. 125, 541 (1990).

10. Ko, F. I., Chen, J.-P., and Weissman, J. G., J. Catal. 105, 511 (1987).

11. Itoh, M., Hattori, H., and Tanabe, K., J. Catal. 35, 225 (1974).

12. Lopaz, T., React. Kinet. Catal. Lett. 47(1), 21(1992).

13. Ramirez, J., Fuentes, S., Diaz, G., Vrinat, M., Breysse, M., and Lacroix, M., Appl. Catal. 52, 211 (1989).

14. Valyon, J., Henker, M., and Wendlandt, K-P., React. Kinet. Catal. Lett. 38(2), 273 (1989).

15. Valyon, J., Henker, M., and Wendlandt, K.-P., React. Kinet. Catal. Lett. 38(2), 265 (1989).

16. Muralidhar, G., Massoth, F. F., and Shabtai, J., J. Catal. 85, 44 (1984).

17. Saini, A. R., Johnson, B. G., and Massoth, F. F., Appl. Catal. 40, 157 (1988).

18. Ramirez, J., Ruiz-Ramirez, L., Cedeno, L., Harle, V., Vrinat, M., and Breysse, M., Appl. Catal. A 93, 163 (1993).

19. Damyanova, S., Spojakina, A., and Jiratova, K., Appl. Catal. A 125,

20. Weissman, J. G., Ko, F. I., and Kaytal, S., Appl. Catal. 94, 45 (1993).

21. Daly, F P, Ando, H., Schmitt, J. L., and Sturm, F. A., J. Catal. 108,401 (1987).

22. Gulkova, D., and Vit, Z., Appl. Catal. A 125, 61(1995).

23. Miller, J. B., Rankin, S. F., and Ko, F. I., J. Catal. 148, 673 (1994). 
24. Chang, R.-C., and Wang, I., J. Catal. 107, 195 (1987).

25. Cui, J.-W., Massoth, F. F., and Topsoe, N.-Y., J. Catal. 136, 361 (1992).

26. Hutter, R., Mallat, T., and Baiker, A., J. Catal. 153, 177 (1995).

27. Veluswamy, S. R., Ph.D. Dissertation, University of Utah, 1977.

28. Dosch, R. G., Stephens, H. P., and Stohl, F. V., U.S. Patent 4,511,455 (1985).

29. Stephens, H. P., and Dosch, R. G., in "Preparation of Catalysts IV" (B. Delmon, P. Grange, P. A. Jacobs, and G. Poncelet, Eds.), Stud. Surf Sci. Catal., Vol. 31. 1987.

30. Dosch, R. G., Stohl, F V., and Richardson, J. T, Am. Chem. Soc. Symp. Ser. 437, 279 (1990).

31. Monnier, J., Denes, G., Potter, J., and Kriz, F, Energy\&Fuels 1, 332 (1987).

32. Stephens, H. P., Dosch, R. G., and Stohl, F V., Ind. Eng. Chem. Prod. Res. Dev. 24, 15 (1985).

33. Stephens, H. P., and Dosch, R. G., in "Proceedings, 9th International Congress on Catalysis Calgary, 1988" (M. J. Phillips and M. Ternan, Eds.), Vol. 1, p. 160. Chem. Institute of Canada, Ottawa, 1988.

34. Anthony, R. G., and Dosch, R. G., in "Catalysts IV" (B. Delmon, P. Grange, P. A. Jacobs, and G. Poncelet, Eds.), p. 637. Stud. Surf. Sci. Catal., Vol:63. 1991.

35. Anthony, R. G., Gonzalez, F., Philip, C. V., and Dosch, R. G., Catal. Today 14,253 1992.

36. Dosch, R. G., and McLaughlin, L. I., SAND92-0388, Sandia National Laboratories (1992).

37. Mochida, I., Takarabe, A., and Takeshita, K., Fuel 58, 17 (1979).

38. Derbyshire, F J., and Whitehurst, D. D., Fuel 60, 655 (1981).

39. Kuhlmann, F. J., Jung, D. Y., Guptill, R. F, Dyke, C. A., and Zang, H. K., Fuel 64, 1552 (1985). 


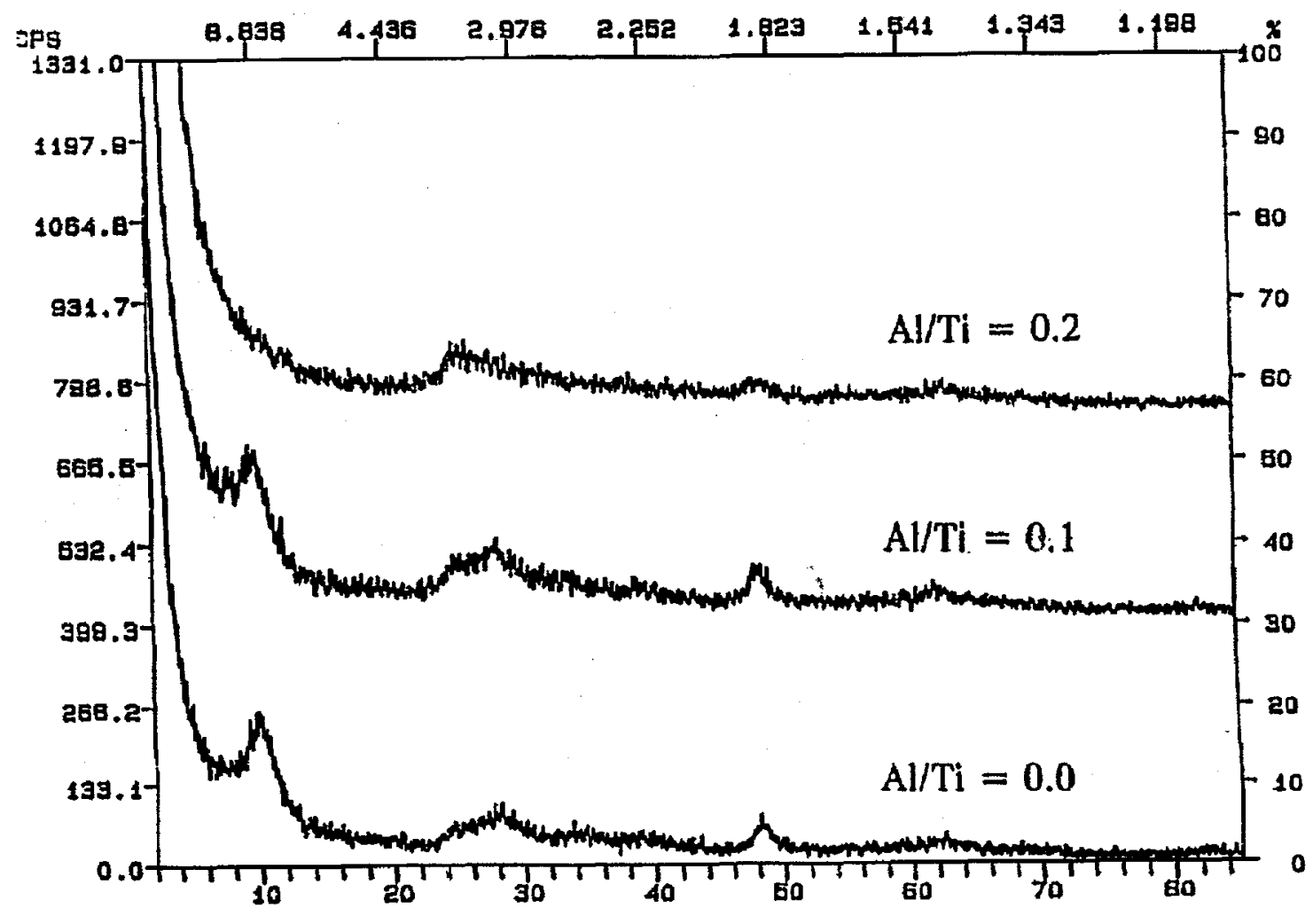

Figure 1. XRD patterns of the as-prepared Si-Al-Ti samples. NT54-56, with constant Si/Ti mole ratio of 0.25 and $\mathrm{Al} / \mathrm{Ti}$ mole ratios at $0,0.1$, and 0.2 . respectively. 


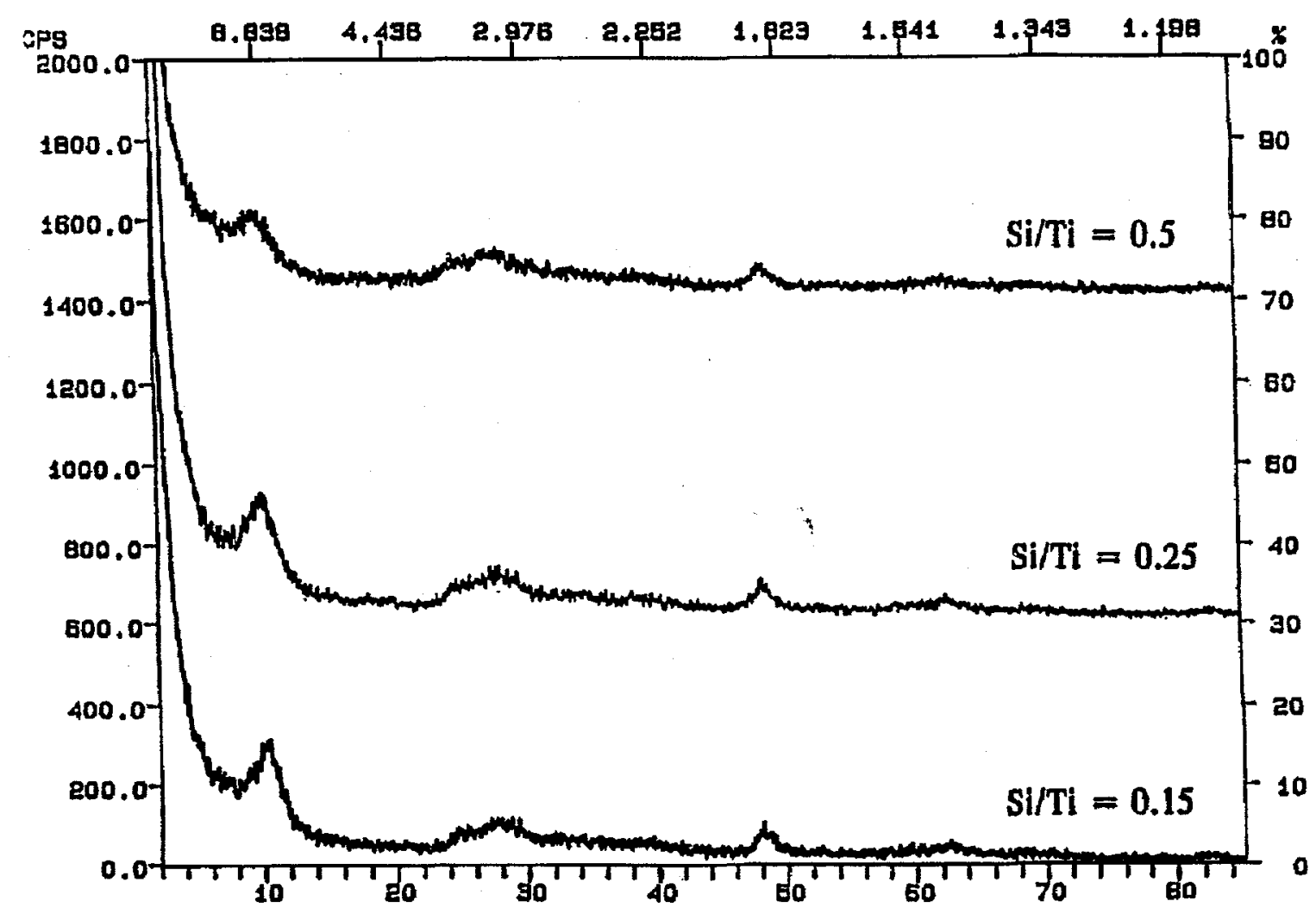

Figure 2. XRD patterns of the as-prepared Si-Al-Ti samples. NT57-59, with constant Al/Ti mole ratio of 0.05 and $\mathrm{Si} / \mathrm{Ti}$ mole ratios of $0.15,0.25$ and 0.5 . respectively. 


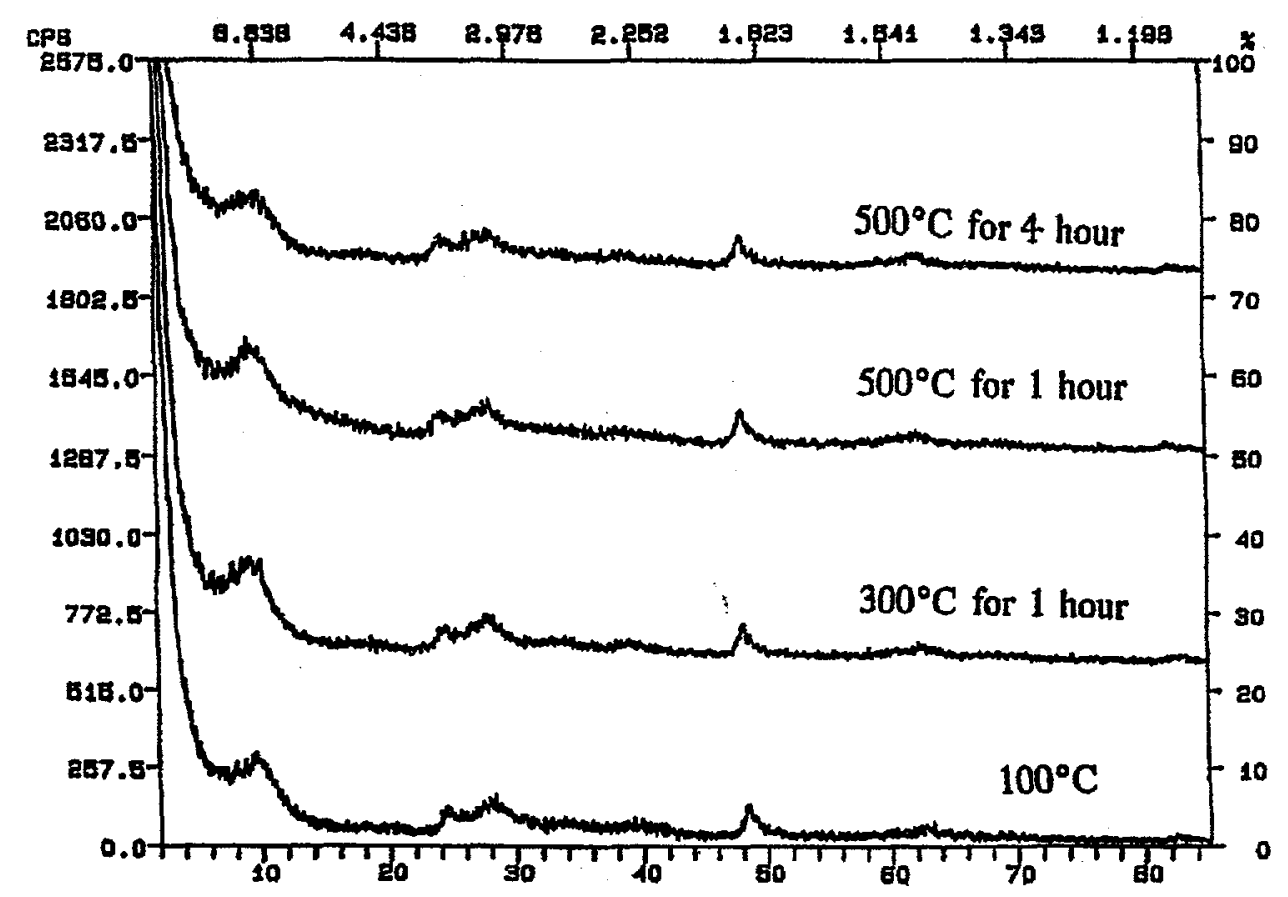

Figure 3. XRD patterns of the sodium form $\mathrm{Si}-\mathrm{Al}-\mathrm{Ti}$ samples with $\mathrm{Si} / \mathrm{Ti}=0.25$ and $\mathrm{Al} / \mathrm{Ti}=0.5$ after calcination at different temperatures.

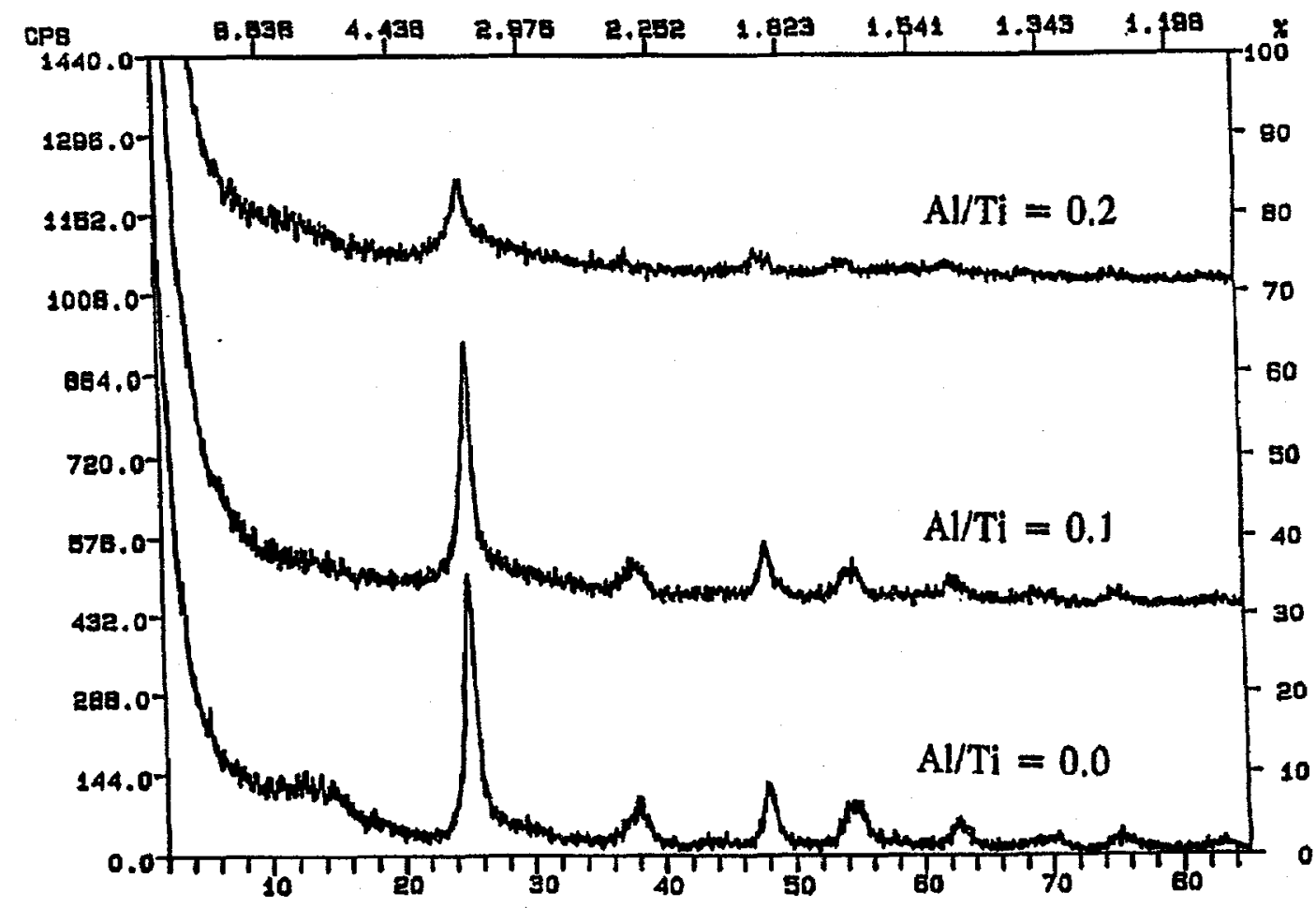

Figure 4. XRD patterns of the acidified Si-Al-Ti samples with NT54-56, $\mathrm{Si} / \mathrm{Ti}=0.25$ and $\mathrm{Al} / \mathrm{Ti}^{\mathrm{N}}=0-0.2$ after calcination at $500^{\circ} \mathrm{C}$ for $4 \mathrm{~h}$. 


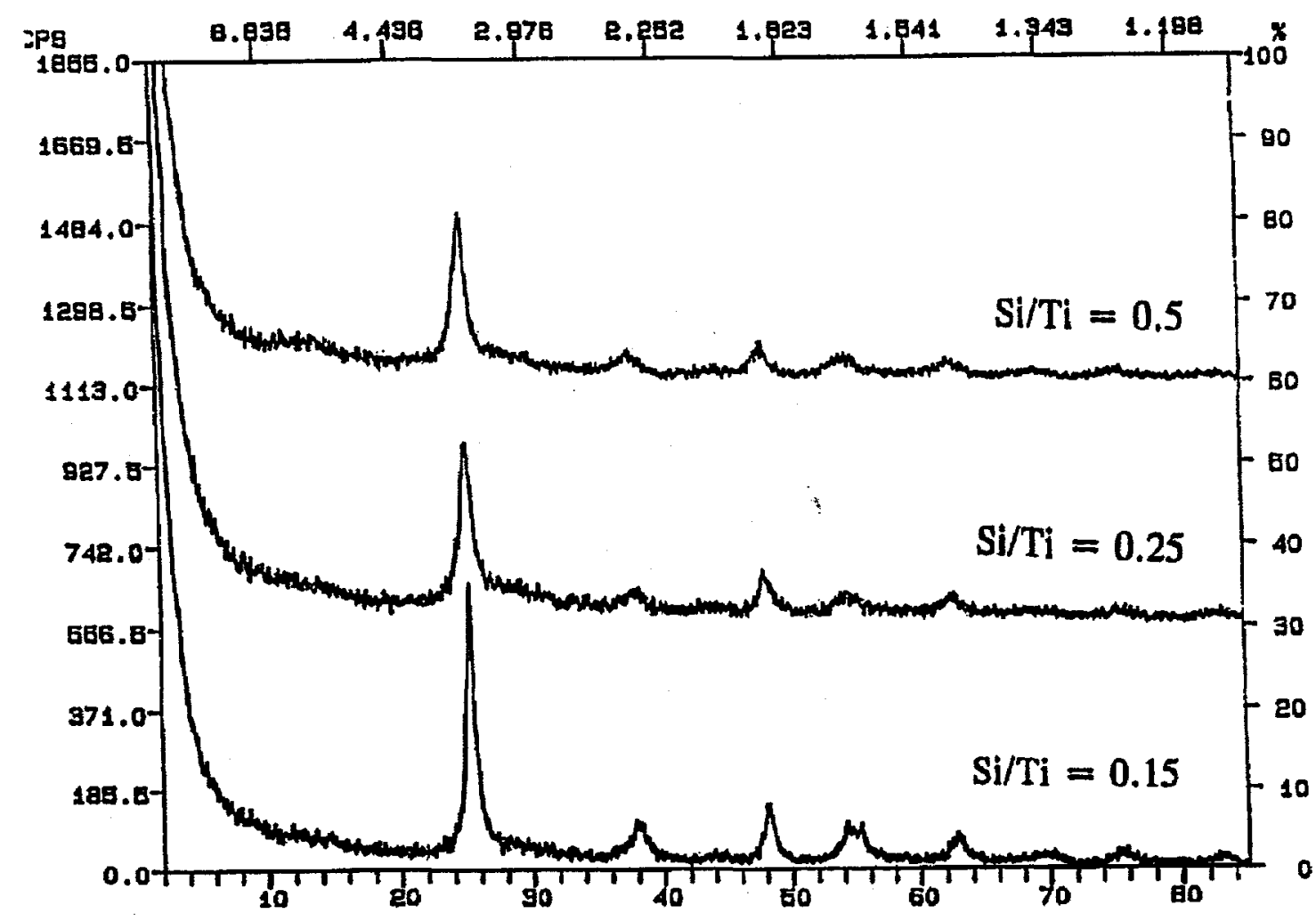

Figure 5. XRD patterns of the acidified $\mathrm{Si}-\mathrm{Al}-\mathrm{Ti}$ samples, $\mathrm{Al} / \mathrm{Ti}=0.5, \mathrm{Si} / \mathrm{Ti}=0.15-0.5$, after calcination at $500^{\circ} \mathrm{C}$ for $4 \mathrm{~h}$.

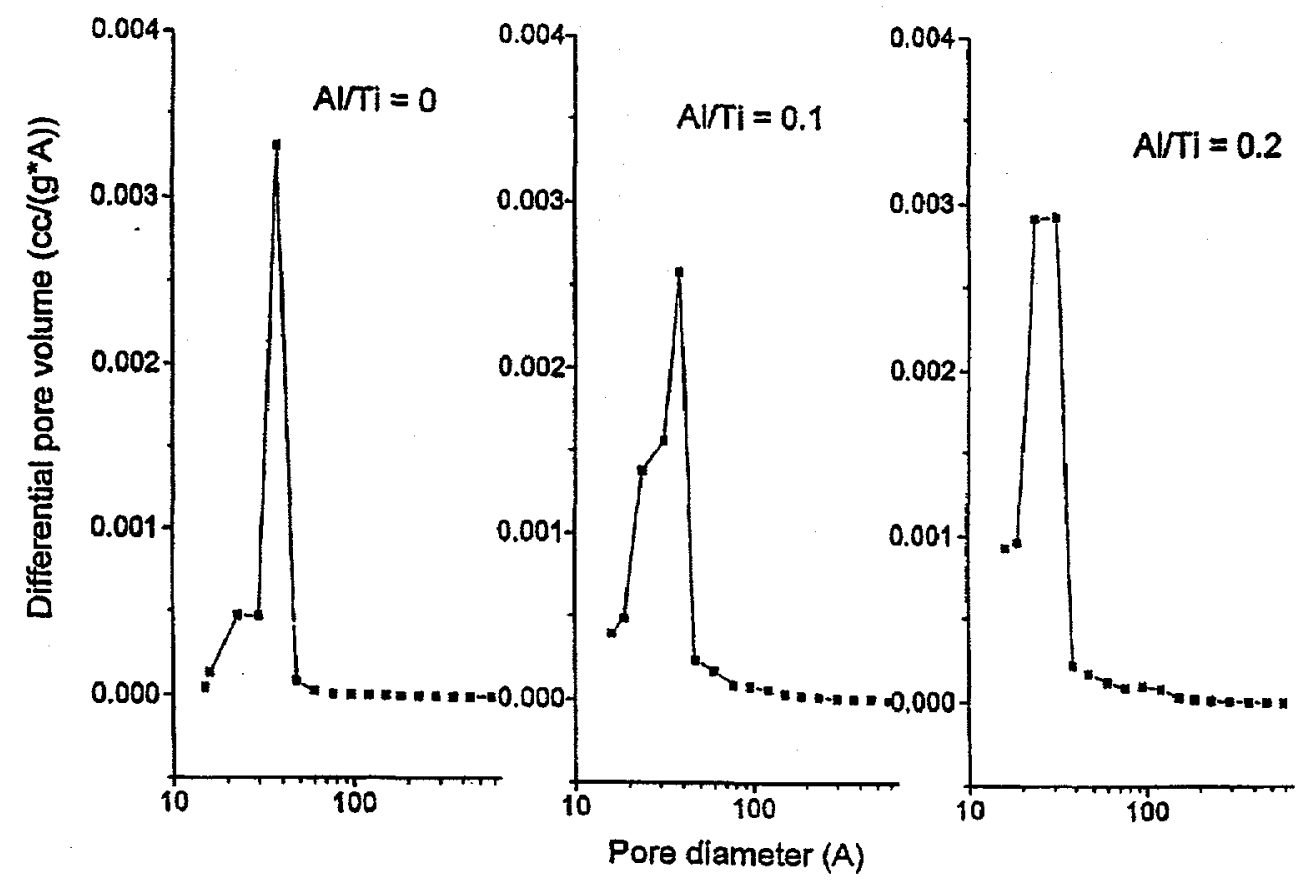

Figure 6. Effect of silica content on the different pore volume distribution plots of Si-Al-Ti. 


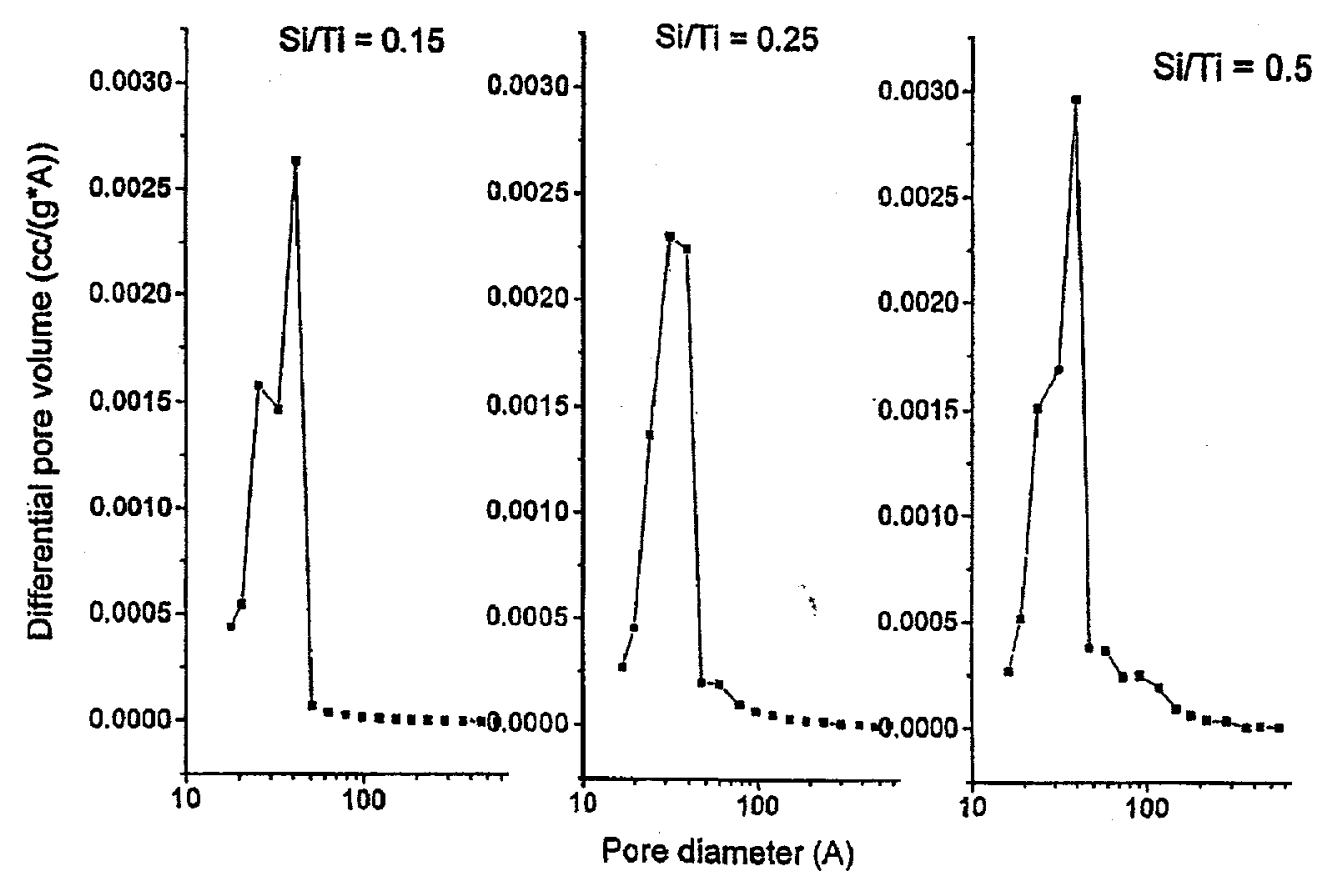

Figure 7. Effect of alumina content on the different pore volume distribution plots of Si-Al-Ti.

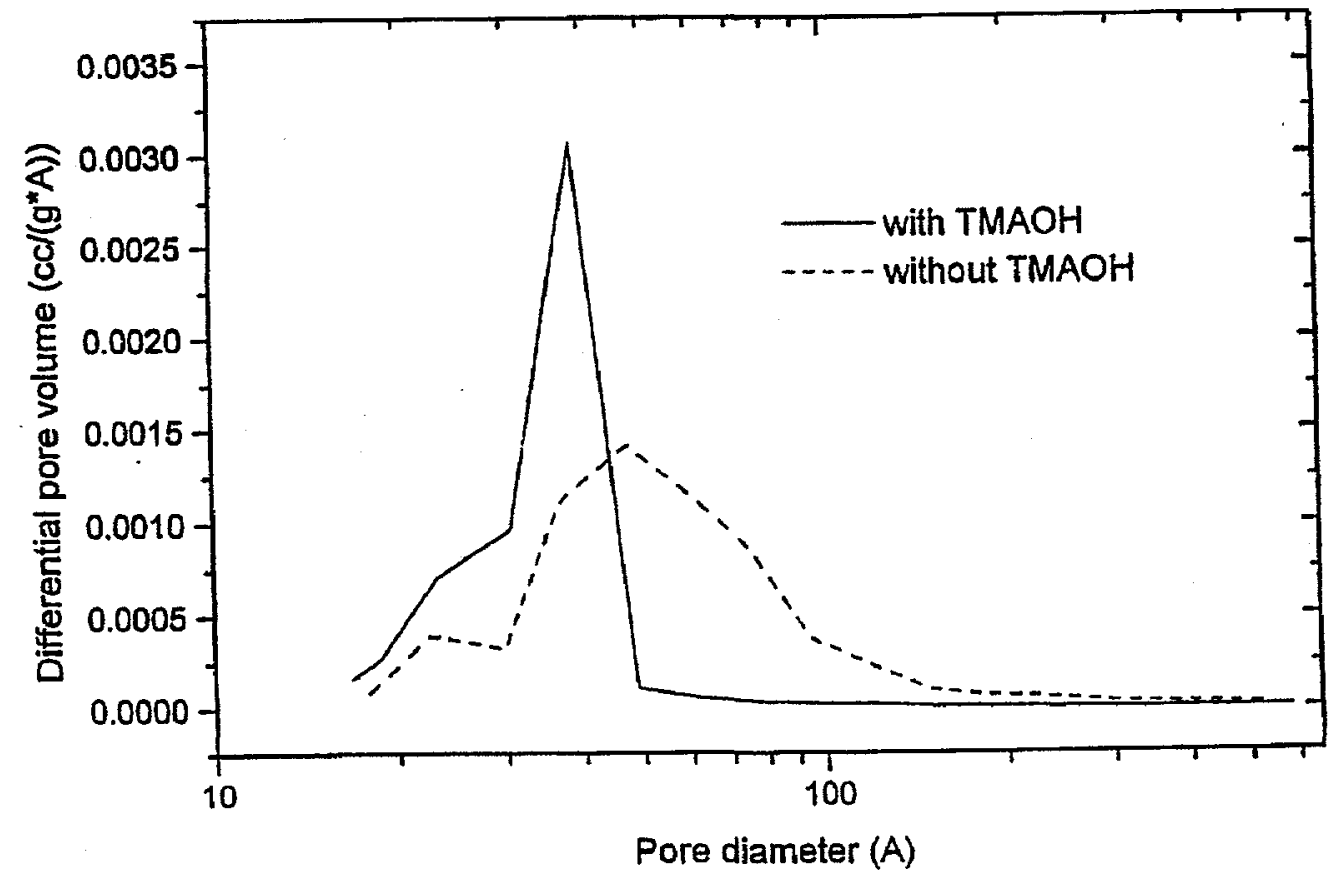

Figure 8. Effect of organic template, TMAOH, on the different pore volume distribution plots of Si-Al-Ti. 


\section{TABLE 1}

Synthesis Conditions and the Final Product Composition of the Si-Al-Ti Supports

\begin{tabular}{|l|c|c|c|c|c|c|}
\hline S-Al-Ti & $\begin{array}{c}\text { Synthesis } \\
\text { temperature }\left({ }^{\circ} \mathrm{C}\right)\end{array}$ & $\begin{array}{c}\text { Reactor } \\
\text { volume }(\mathrm{ml})\end{array}$ & $\begin{array}{c}\text { Si/Ti } \\
\text { synthesis }\end{array}$ & $\begin{array}{c}\text { Al/Ti } \\
\text { synthesis }\end{array}$ & $\begin{array}{c}\text { Si/Ti } \\
\text { measured }\end{array}$ & $\begin{array}{c}\text { Al/Ti } \\
\text { measured }\end{array}$ \\
\hline NT51 & 170 & 600 & 0.25 & 0.05 & 0.186 & 0.033 \\
\hline NT52 & 170 & 75 & 0.15 & 0.05 & 0.120 & 0.027 \\
\hline NT53 & 170 & 75 & 0.50 & 0.05 & 0.370 & 0.039 \\
\hline NT54 & 150 & 75 & 0.25 & 0.0 & 0.072 & 0.002 \\
\hline NT55 & 150 & 75 & 0.25 & 0.1 & 0.161 & 0.040 \\
\hline NT56 & 150 & 75 & 0.25 & 0.2 & 0.213 & 0.095 \\
\hline NT57 & 170 & 600 & 0.15 & 0.05 & 0.115 & 0.027 \\
\hline NT58 & 170 & 600 & 0.25 & 0.05 & 0.166 & 0.039 \\
\hline NT59 & 170 & 600 & 0.50 & 0.05 & 0.365 & 0.046 \\
\hline NT60 & 170 & 600 & 0.25 & 0.05 & 0.159 & 0.041 \\
\hline
\end{tabular}

\section{TABLE 2}

Surface Area, Pore Volume, and Average Pore Diameter of the Si-Al-Ti Supports Resulting from Different Pretreatment

\begin{tabular}{|c|c|c|c|c|c|c|}
\hline Support\# & Support description & $\begin{array}{l}\mathrm{Si} / \mathrm{Ti} \\
\text { synthesis }\end{array}$ & $\begin{array}{l}\text { Al/Ti } \\
\text { synthesis }\end{array}$ & $\begin{array}{l}\text { Surface area } \\
\qquad\left(\mathrm{m}^{2} / \mathrm{g}\right)\end{array}$ & $\begin{array}{l}\text { Total pore } \\
\text { volume }\left(\mathrm{cm}^{3} / \mathrm{g}\right)\end{array}$ & $\begin{array}{l}\text { Average pore } \\
\text { diameter (A) }\end{array}$ \\
\hline & Acidified and then calcined ${ }^{2}$ NT54 & 0.25 & 0.0 & 136 & 0.16 & 37.5 \\
\hline 2 & Acidified and then calcined NT55 & 0.25 & 0.1 & 232 & 0.27 & 38.7 \\
\hline 3 & Acidified and then calcined NT56 & 0.25 & 0.2 & 367 & 0.36 & 38.6 \\
\hline $4,7,10,11$ & Acidified and then calcined NT51 & 0.25 & 0.05 & 174 & 0.20 & 38.6 \\
\hline 5 & Acidified and then calcined NT57 & 0.15 & 0.05 & 156 & 0.18 & 38.4 \\
\hline 6 & Acidified and then calcined NT59 & 0.5 & 0.05 & 193 & 0.31 & 37.2 \\
\hline 8 & Acidified and then calcined NT52 & 0.15 & 0.05 & 161 & 0.20 & 38.4 \\
\hline 9 & Acidified and then calcined NT53 & 0.5 & 0.05 & 192 & n.m. & n.m. \\
\hline t2 & Acidified NT51 & 0.25 & 0.05 & n.m. & n.m. & n.m. \\
\hline 13 & Calcined and then acidified NT57 & 0.15 & 0.05 & 155 & 0.23 & 37.2 \\
\hline 14 & Calcined and then acidified NT58 & 0.25 & 0.05 & 157 & 0.30 & 36.4 \\
\hline 15 & Calcined and then acidified NT59 & 0.5 & 0.05 & 211 & 0.43 & 37.2 \\
\hline 16 & Acidified and then calcined NT 60 & 0.25 & 0.05 & 201 & 0.43 & 47.0 \\
\hline 17 & Calcined and then acidified NT60 & 0.25 & 0.05 & 176 & 0.74 & $186.0,36.2$ \\
\hline 18 & Acidified NT57 & 0.15 & 0.05 & 241 & 0.23 & 41.0 \\
\hline 19 & Acidified NT58 & 0.25 & 0.05 & 250 & 0.38 & 31.7 \\
\hline 20 & Acidified NT59 & 0.5 & 0.05 & 287 & 0.38 & 39.2 \\
\hline
\end{tabular}

Note. n.m., not measured

a The support was acidified using sulfuric acid and calcined at $500^{\circ} \mathrm{C}$ for $4 \mathrm{~h}$. 


\section{TABLE 3}

The Physical Properties of the NiMo/Si-Al-Ti Catalysts and a Commercial Catalyst (Shell 324) and Their Catalytic Activities for Pyrene Hydrogenation

\begin{tabular}{|c|c|c|c|c|c|c|c|c|c|}
\hline Catalyst\# & Mo Loading ${ }^{a}$ & $\begin{array}{c}\text { Mo } \\
(w t \%)\end{array}$ & $\begin{array}{c}\text { NI } \\
(w t \%)\end{array}$ & $\begin{array}{c}\mathrm{Si} / \mathrm{Ti} \\
\text { synthesis }\end{array}$ & $\begin{array}{c}\mathrm{Al} / \mathrm{Ti} \\
\text { synthesis }\end{array}$ & $\begin{array}{c}\text { Surface area } \\
\left(\mathrm{m}^{2} / \mathrm{g}\right)\end{array}$ & $\begin{array}{c}\text { Pretreat- } \\
\text { ment }^{b}\end{array}$ & $\begin{array}{c}\text { khyd.total } \\
(\mathrm{g} \text { of catalyst } \mathrm{s})^{-1}\end{array}$ & $\begin{array}{c}\text { hyd.Mo } \\
\text { (g of Mo s) })^{-1}\end{array}$ \\
\hline Shell 324 & - & 13.2 & 2.7 & - & - & 152 & $\mathrm{~s}$ & 0.18 & 1.33 \\
\hline 1 & Impr. $\mathrm{HNO}_{3}$ & 7.21 & 2.60 & 0.25 & 0.0 & 136 & $\mathrm{C}$ and $\mathrm{S}$ & 0.073 & 1.01 \\
\hline 2 & Impr. $\mathrm{HNO}_{3}$ & 8.52 & n.m. & 0.25 & 0.1 & 232 & $\begin{array}{l}\mathrm{C} \text { and } \mathrm{S} \\
\mathrm{S}\end{array}$ & $\begin{array}{l}0.15 \\
0.12\end{array}$ & $\begin{array}{c}1.8 \\
1.36\end{array}$ \\
\hline 3 & Impr. $\mathrm{HNO}_{3}$ & 9.01 & 2.50 & 0.25 & 0.2 & 367 & $\begin{array}{l}\mathrm{C} \text { and } \mathrm{S} \\
\mathrm{S}\end{array}$ & $\begin{array}{l}0.10 \\
0.11\end{array}$ & $\begin{array}{l}1.14 \\
1.27\end{array}$ \\
\hline 4 & Impr. $\mathrm{HNO}_{3}$ & 7.51 & n.m. & 0.25 & 0.05 & 174 & $\begin{array}{l}\mathrm{C} \text { and } \mathrm{S} \\
\mathrm{S}\end{array}$ & $\begin{array}{l}0.11 \\
0.12\end{array}$ & $\begin{array}{l}1.43 \\
1.57\end{array}$ \\
\hline 5 & Impr. $\mathrm{HNO}_{3}$ & 7.00 & 2.56 & 0.15 & 0.05 & 156 & $\begin{array}{l}\mathrm{C} \text { and } \mathrm{S} \\
\mathrm{S}\end{array}$ & $\begin{array}{l}0.09 \\
0.12\end{array}$ & $\begin{array}{l}1.33 \\
1.53\end{array}$ \\
\hline 6 & Impr. $\mathrm{HNO}_{3}$ & 8.49 & 2.36 & 0.5 & 0.05 & 193 & $\begin{array}{l}\mathrm{C} \text { and } \mathrm{S} \\
\mathrm{S}\end{array}$ & $\begin{array}{l}0.15 \\
0.15\end{array}$ & $\begin{array}{l}1.75 \\
1.74\end{array}$ \\
\hline 7 & Ion Ex. & 24.65 & 6.23 & 0.25 & 0.05 & 174 & $\begin{array}{l}\mathrm{C} \text { and } \mathrm{S} \\
\mathrm{S}\end{array}$ & $\begin{array}{l}0.04 \\
0.10\end{array}$ & $\begin{array}{l}0.16 \\
0.40\end{array}$ \\
\hline 8 & Ion Ex. & 23.78 & n.m. & 0.15 & 0.05 & 161 & $\begin{array}{l}\mathrm{C} \text { and } \mathrm{S} \\
\mathrm{S}\end{array}$ & $\begin{array}{l}0.05 \\
0.09\end{array}$ & $\begin{array}{l}0.22 \\
0.39\end{array}$ \\
\hline 9 & Ion Ex. & 17.37 & n.m. & 0.5 & 0.05 & 192 & $\begin{array}{l}\mathrm{C} \text { and } \mathrm{S} \\
\mathrm{S}\end{array}$ & $\begin{array}{l}0.12 \\
0.09\end{array}$ & $\begin{array}{l}0.70 \\
0.51\end{array}$ \\
\hline 10 & Impr. $\mathrm{H}_{2} \mathrm{SO}_{4}$ & 6.57 & n.m. & 0.25 & 0.05 & 174 & $\begin{array}{l}C \text { and } S \\
S\end{array}$ & $\begin{array}{l}0.11 \\
0.08\end{array}$ & $\begin{array}{l}1.68 \\
1.28\end{array}$ \\
\hline 11 & Impr. & 7.21 & n.m. & 0.25 & 0.05 & 174 & $\begin{array}{l}\mathrm{C} \text { and } \mathrm{S} \\
\mathrm{S}\end{array}$ & $\begin{array}{l}0.12 \\
0.06\end{array}$ & $\begin{array}{l}1.62 \\
0.89\end{array}$ \\
\hline 12 & Ion Ex. & 7.96 & 1.65 & 0.25 & 0.05 & n.m. & $\begin{array}{l}\mathrm{C} \text { and } \mathrm{S} \\
\mathrm{S}\end{array}$ & $\begin{array}{l}0.13 \\
0.02\end{array}$ & $\begin{array}{l}1.65 \\
0.25\end{array}$ \\
\hline 13 & Impr. $\mathrm{HNO}_{3}$ & 7.47 & n.m. & 0.15 & 0.05 & 155 & $\begin{array}{l}\mathrm{C} \text { and } \mathrm{S} \\
\mathrm{S}\end{array}$ & $\begin{array}{l}0.08 \\
0.03\end{array}$ & $\begin{array}{l}1.13 \\
0.47\end{array}$ \\
\hline 14 & Impr. $\mathrm{HNO}_{3}$ & 7.80 & n.m. & 0.25 & 0.05 & 157 & $\begin{array}{l}\mathrm{C} \text { and } \mathrm{S} \\
\mathrm{S}\end{array}$ & $\begin{array}{l}0.11 \\
0.03\end{array}$ & $\begin{array}{c}1.4 \\
0.36\end{array}$ \\
\hline 15 & Impr. $\mathrm{HNO}_{3}$ & 7.77 & n.m. & 0.5 & 0.05 & 211 & $\begin{array}{l}\mathrm{C} \text { and } \mathrm{S} \\
\mathrm{S}\end{array}$ & $\begin{array}{l}0.16 \\
0.10\end{array}$ & $\begin{array}{l}2.0 \\
1.3\end{array}$ \\
\hline 16 & Impr. $\mathrm{HNO}_{3}$ & 8.23 & 2.39 & 0.25 & 0.05 & 201 & $\begin{array}{l}\mathrm{C} \text { and } \mathrm{S} \\
\mathrm{S}\end{array}$ & $\begin{array}{l}0.19 \\
0.19\end{array}$ & $\begin{array}{l}2.3 \\
2.3\end{array}$ \\
\hline 17 & Impr. $\mathrm{HNO}_{3}$ & 8.78 & 2.48 & 0.25 & 0.05 & 176 & $\begin{array}{l}\mathrm{C} \text { and } \mathrm{S} \\
\mathrm{S}\end{array}$ & $\begin{array}{l}0.13 \\
0.18\end{array}$ & $\begin{array}{l}1.5 \\
2.0\end{array}$ \\
\hline 18 & Impr. $\mathrm{HNO}_{3}$ & n.m. & n.m. & 0.15 & 0.05 & 241 & $\begin{array}{l}\mathrm{C} \text { and } \mathrm{S} \\
\mathrm{S}\end{array}$ & $\begin{array}{l}0.14 \\
0.05\end{array}$ & - \\
\hline 19 & Impr. $\mathrm{HNO}_{3}$ & n.m. & n.m. & 0.25 & 0.05 & 250 & $\begin{array}{l}\mathrm{C} \text { and } \mathrm{S} \\
\mathrm{S}\end{array}$ & $\begin{array}{l}0.15 \\
0.09\end{array}$ & - \\
\hline 20 & Impr. $\mathrm{HNO}_{3}$ & 9.03 & 2.56 & 0.5 & 0.05 & 287 & $\begin{array}{l}\mathrm{C} \text { and } \mathrm{S} \\
\mathrm{S}\end{array}$ & $\begin{array}{l}0.15 \\
0.12 \\
\end{array}$ & $\begin{array}{l}1.7 \\
1.3 \\
\end{array}$ \\
\hline
\end{tabular}

Note: Tables 3's catalyst\# and Table 2's support\# are similar identifiers. n.m., not measured.

${ }^{2}$ There are four different impregnation methods: Impr. $\mathrm{HNO}_{3}$, impregnation with $\mathrm{HNO}_{3} ; \mathrm{Impr} . \mathrm{H}_{2} \mathrm{SO}_{4}$, impregnation with $\mathrm{H}_{2} \mathrm{SO}_{4}$; Impr., impregnation with no acid; Ion Ex., impregnation with ion exchange.

${ }^{b}$ There are two procedures used to activate the catalysts: $\mathrm{S}$, the catalysts were sulfided at $420^{\circ} \mathrm{C}$ only; $\mathrm{C}$ and $\mathrm{S}$, the catalysts were calcined at $500^{\circ} \mathrm{C}$ and sulfided at $420^{\circ} \mathrm{C}$. 
TABLE 4

The Most Active Catalysts Evaluated in This Investigation

\begin{tabular}{|c|c|c|c|c|c|c|c|c|c|c|}
\hline Cat ID & $\mathrm{Si} / \mathrm{Ti}$ & $\mathrm{Al} / \mathrm{Ti}$ & & $\begin{array}{c}\text { Methods } \\
\text { of } \\
\text { Treatment }\end{array}$ & & $\begin{array}{c}\text { Surface } \\
\text { area } \\
\left(\mathrm{m}^{2} / \mathrm{g}\right)\end{array}$ & $\begin{array}{c}\begin{array}{c}\text { Pore } \\
\text { volume } \\
(\mathrm{ml} / \mathrm{g})\end{array} \\
\end{array}$ & $\begin{array}{l}\text { Avg. pore } \\
\text { diameter } \\
(\mathrm{nm})\end{array}$ & $\begin{array}{c}\text { Mo (Ni) } \\
\text { (wt\%) }\end{array}$ & $\begin{array}{c}\text { Activity } \\
(\mathrm{k}, 1 /(\mathrm{g}-\mathrm{s}) \text { and } \\
(\mathrm{V} /(\mathrm{g} \text { Mo-s })))\end{array}$ \\
\hline$\# 2$ (NT55) & 0.161 & 0.04 & A\&C & Imprg. & $\mathrm{C} \& \mathrm{~S}$ & 232 & 0.27 & 39 & $8.5(\mathrm{NM})$ & $0.15(1.75)$ \\
\hline \#6 (NT59) & 0.365 & 0.046 & A\&C & Imprg. & $\mathrm{C} \& \mathrm{~S}$ & 193 & 0.31 & 37 & $8.5(2.4)$ & $0.15(1.75)$ \\
\hline$\# 10(\mathrm{NT} 51)$ & 0.186 & 0.033 & $A \& C$ & $\begin{array}{c}\text { Imprg. sulfuric } \\
\text { acid }\end{array}$ & C\&S & 174 & 0.2 & 39 & $6.6(\mathrm{NM})$ & $0.11(1.7)$ \\
\hline$\# 11$ (NT51) & 0.186 & 0.033 & $A \& C$ & Imprg. & $\mathrm{C} \& \mathrm{~S}$ & 174 & 0.2 & 39 & $7.2(\mathrm{NM})$ & $0.12(1.6)$ \\
\hline$\# 12$ (NT51) & 0.186 & 0.033 & $\mathrm{~A}$ & Ion ex. & $\mathrm{C} \& \mathrm{~S}$ & $\mathrm{NM}$ & NM & $\mathrm{NM}$ & $8(1.7)$ & $0.13(1.6)$ \\
\hline$\# 16($ NT60) & 0.159 & 0.041 & A\&C & Imprg. & $\mathrm{C \& S}$ & 201 & 0.43 & 47 & $8.2(2.4)$ & $0.19(2.3)$ \\
\hline$\# 17$ (NT60) & 0.159 & 0.041 & C\&A & Imprg. & 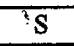 & 176 & 0.74 & 186,36 & $8.8(2.5)$ & $0.18(2.0)$ \\
\hline Shell 324 & $\mathrm{~N} / \mathrm{A}$ & N/A & $\mathrm{N} / \mathrm{A}$ & Imprg. & C\&S & 152 & $\mathrm{NM}$ & NM & $13.2(2.7)$ & $0.18(1.3)$ \\
\hline
\end{tabular}

Note. NM, not measured; imprg., impregnation with $\mathrm{pH}$ control using nitric acid. Ion exchange is anion exchange with $\mathrm{pH}$ control with nitric acid.

$\mathrm{A} \& \mathrm{C}$, acidified and calcined; $\mathrm{C} \& \mathrm{~S}$, calcined and then sulfided; S, sulfided only. 